\title{
UTR extension and alternate polyadenylation in neuroplasticity: an emerging paradigm?
}

\author{
Benjamin J Harrison ${ }^{1 \dagger}$, Robert M Flight ${ }^{2 \dagger}$, Abdallah M Eteleeb ${ }^{3 \dagger}$, Eric C Rouchka ${ }^{3 *}$, Jeffrey C Petruska ${ }^{1,4,5^{*}}$ \\ From UT-KBRIN Bioinformatics Summit 2014 \\ Cadiz, KY, USA. 11-13 April 2014
}

\section{Background}

The 3'-untranslated region (3'UTR) of mRNA transcripts contributes to cell-type specific or developmental-stage specific regulation of gene functions by modifying cellular localization, stability and/or translational efficiency of transcripts.

\section{Materials and methods}

Using RNA-seq to profile transcripts from neural tissue undergoing axonal plasticity, we detected approximately 1000 previously uncharacterized 3'UTR sequences, of which more than 100 are highly regulated when plasticity is induced.

\section{Results}

Computational analyses of the novel UTR sequences, focusing on RNA-binding protein (RNAbp) interaction motifs revealed strongly over-represented RNAbps with known roles in nervous system pathologies. We consider the implications of 3'UTR transcript extension and protein interaction in the context of axonal plasticity and the consequences of mis-regulation of this process during neurological disease.

\section{Authors' details}

'Department of Anatomical Sciences and Neurobiology, University of Louisville, Louisville, KY 40202, USA. ${ }^{2}$ Department of Cellular and Molecular Biochemistry, University of Kentucky, Lexington, KY, 40508, USA. ${ }^{3}$ Department of Computer Engineering and Computer Science, University of Louisville, Louisville, KY 40292, USA. ${ }^{4}$ Department of Neurological Surgery, University of Louisville, Louisville, KY 40202, USA. ${ }^{5}$ Kentucky Spinal Cord Injury Research Center, University of Louisville, Louisville, KY 40202, USA.

\footnotetext{
* Correspondence: eric.rouchka@louisville.edu; j.petruska@louisville.edu + Contributed equally

'Department of Anatomical Sciences and Neurobiology, University of Louisville, Louisville, KY 40202, USA

${ }^{3}$ Department of Computer Engineering and Computer Science, University of Louisville, Louisville, KY 40292, USA

Full list of author information is available at the end of the article
}

Published: 29 September 2014

doi:10.1186/1471-2105-15-S10-P11

Cite this article as: Harrison et al:: UTR extension and alternate polyadenylation in neuroplasticity: an emerging paradigm? BMC Bioinformatics 2014 15(Suppl 10):P11.
Submit your next manuscript to BioMed Central and take full advantage of:

- Convenient online submission

- Thorough peer review

- No space constraints or color figure charges

- Immediate publication on acceptance

- Inclusion in PubMed, CAS, Scopus and Google Scholar

- Research which is freely available for redistribution
() Biomed Central 